\title{
Assessing Factors that Prevent Female Students from Studying Hotel Management: A Case Study of the University of Jordan (Aqaba Branch)
}

\author{
Omar Jawabreh \\ Department of Hotel Management, Faculty of Tourism and Hospitality \\ The University of Jordan \\ E-mail: o.jawabreh@ju.edu.jo
}

Bushra Alaqrarah

Department of Hotel Management, Faculty of Tourism and Hospitality

The University of Jordan

Hossam Al Hrerat

Department of Hotel Management, Faculty of Tourism and Hospitality

The University of Jordan

\begin{abstract}
Ismail Al Shaabatat
Department of Hotel Management, Faculty of Tourism and Hospitality

The University of Jordan
\end{abstract}

Qatada Al Jarah

Department of Hotel Management, Faculty of Tourism and Hospitality

The University of Jordan

Received: Jan. 16, 2017

doi:10.5296/jmr.v9i4.11690
Accepted: Sep. 15, 2017

Published: October 1, 2017

URL: https://doi.org/10.5296/jmr.v9i4.11690 


\section{Abstract}

The participation of women in the hospitality industry is crucial. This research is conducted to explore factors that prevent female students from studying hotel management as a major at the Faculty of Tourism and Hospitality in the University of Jordan, located in Jordan. These factors include the financial aspects, cultural and social standpoints, religious perspective, and geographical reason. A total of 200 questionnaires containing 24 items was used to collect information from bachelor students at the University of Jordan-Aqaba. Results of the current study revealed that all the above barriers are applied to high levels in which the range of the mean score is 3.49-3.82. This study shall provide important feedback to decision-makers to encourage the female students further in studying hotel management degree specifically in Aqaba city.

Keywords: Hotel Management, Jordan, Financial Barriers, Cultural and Social Barriers, Religious Barriers, Geographical Barriers, Aqaba. 


\section{Introduction}

Tourism is considered the most lucrative industry all over the world; it could be the first industry in a country or could be the second or the third largest industry in some countries (Fall, 2002). Tourism is recognized for development, economic progress, and revitalization; its fundamental contribution to the growth of the economy is one of the main reasons behind the interest of countries to develop and promote tourism attractions. It is considered as an increasing industry, its wealth could be redistributed to other sectors and destinations. It is a free trade without barriers, borders or restrictions; it depends mostly on natural infrastructure such as historical sites (Meehan, 2008; Sharpley, 2002). It has become a vital source of economic development (Hodur and Leistritz, 2006). Jordan is a small stable country in the Middle East but comparing to neighboring countries, Jordan suffers from the limitation of its mineral and water resources. Therefore, the government of Jordan has realized early the importance of tourism to support its economy. The revenue from tourism in 2008 accounted for 13 per cent of Jordan's Gross Domestic Product (GDP) according to the statistics of the Ministry of Tourism and Antiquities (MOTA). Jordan depends on the tourism industry as a source of employment. Meanwhile, the majority of employees are males and working in the hotel sector and female employees constitute around $10 \%$ of the labor force in the hotel sector and the majority of them are foreign female employees. Aqaba city is the second touristic destination in Jordan, there are 41 classified hotels and 2660 employees are working in these hotels; 1822 are Jordanian male employees and 59 Jordanian female employees, 692 are non-Jordanian male employees and 87 non-Jordanian female employees (MOTA, 2014).

Tourism services need qualified and skilled staff to present and delivered these services to the customers. Thus, the role of the universities, community colleges, and vocational training centers is magnificent in providing tourism sector with professional employees. There are 28 universities in Jordan, and it is considered a leader among Arab countries in education which plays a remarkable role in the progress and development of Jordan. Tourism and hospitality education also attracts the attention of both the private and public sector. According to the statistic of the Ministry of Higher Education and Scientific Research (2015), the number of students enrolling tourism and hospitality colleges was 3125 in the three majors (Tourism Management, Hotel Management, Food and Beverage Management); among them, 1101 were female students. The least number of female students was in Hotel Management. The statistics also show that the number of students enrolling in Hotel Management Department at the University of Jordan $\backslash$ Aqaba branch in 2015 was 66 among them were six female students while there were 44 female students in Food and Beverage Department out of 80 students and 58 female students in Travel and tourism department out 124 students (Alsarayreh, Abed Alqader, and Jawabreh, 2010; MOHESR, 2016).

Therefore, this study was conducted at the University of Jordan/ Aqaba branch to explore the reasons and factors that prevent female student from studying hotel management. In addition little research was conducting in this area such as (Alananzeh, 2014) who explored the factors that prevent students (male and female) from enrolling Tourism and Hospitality colleges, and the study of Alzou'bi and Alkharouf (2015) to assess students perceptions and attitudes towards women working in tourism sector, but no study was conducted to explore the factors 
that hindering female students from enrolling hotel management department. The study aimed at assessing several factors from the point view of female students who are studying other majors at the University of Jordan regarding the factors that preventing them from studying hotel management, in addition, the study aimed at presenting recommendations for both the local community and tourism stakeholders about the importance of tourism especially hotel sector in providing females with permanent and lucrative jobs. The decision makers could benefit from the findings of this study to encourage local females to study hotel management and provide them with some applicable incentives that could attract them to this industry.

\section{Literature Review}

The hospitality industry is seen as a glamorous one on one side, while on the other it is deemed as being one of low skill, low status and low pay (Riley et al., 2002). There are reports that the sector has a particularly poor image in the eyes of hospitality students, which suggests that the industry may have greater difficulty attracting, recruiting and retaining quality staff (Jenkins, 2001). Eastern communities face a real shortage of female employees in tourism industry comparing to the western communities. Doherty (2004) pointed out that women in the UK hospitality industry make up 67 per cent of the work force in this sector; they conducted a study to explore the main barriers to women's progression to senior management and highlights the long hours associated with managerial roles as a major problem, the finding of the study showed differences between the rights of males and females.

Other researchers who focused on gender discrimination. Kim, Lee, and Chon (2008) identified the reasons why students in undergraduate and graduate level want to study tourism and hospitality management and their study revealed that students realized that working in tourism and hospitality jobs provide them with overseas experiences, self-actualization, and job opportunities. (Lashley,1999) found that the vast majority of students who were recruited to a particular hospitality management programme in the UK displayed preferred learning styles which indicated they enjoy practical activity (Burke, Koyuncu, and Fiksenbaum, 2008) investigated gender differences in the work and career experiences of female and male managers and supervisors in the hospitality and tourism sector in Turkey. Maxwell, McDougall, and Blair (2000) insisted that regardless of governmental legislations of the equality of opportunities at work, there is still evidence of discrimination between women and men across the globe. The discrimination in work place could be connected with women's notion and culture of job opportunities. Women in some societies are still shy of working in hotel sectors and or still thinking that the man is the dominant or they fear that they will stagnate in lower management positions (Hackett, 1981). Mooney and Ryan (2009) pointed out that women are treated unequally as men regarding career positions in hotels. Social factors also impact women work and career promotion in hotel sectors (Burke, 2005).

\subsection{The Jordanian Context}

Jordan depends on the tourism industry as one of the main resources to improve their balance of payments condition (Bazazo, Alananzeh, and Taani, 2016). Recently, this sector has 
witnessed a great change in the infrastructure development (Bazazo and Alananzeh, 2016; Alshawagfih, Alananzeh, and Jawabreh, 2015) number of foreign investment (Alananzeh, Mahmoud, and Ahmed, 2015, Jawabreh, Alananzeh, and Shatnawi, 2015), and the priority in national strategies for public and private organizations (Bazazo et al., 2016; Al-Hussein et al., 2014; Chiu and Alananzeh, 2012a; Chiu and Alananzeh, 2012b). Obviously, these studies and others are going around the rights of women in senior jobs in hotels. On the contrary, this study is trying to explore the reasons and factors that prevent female students from joining hotel management majors in postgraduate studies. Even modern studies have approved that there is no discrimination in recent years regarding gender in hotel positions (Burke, Koyuncu and Fiksenbaum, 2008). Jordan also gives women the same opportunities as for men in all sectors even in the private sector. In tourism industry especially in Aqaba city which is crowded by hotels, we can see that women have occupied senior positions in the hotel sector. Al-saman (2002) showed that women in Jordan realize that working in the tourism sector is very profitable. Thus, several studies were conducted to explore the reasons behind the enrollment of Jordanian women in tourism industries. In 1997, a survey study done by the Vocationational Training Institution to determine the training program need in force market and the employment of women, the study revealed that women refuse to work due to the lack of facilities presents to them by stakeholders. The survey also revealed that a large number of women are working tourism industry in Amman, the capital city of Jordan, but other regions in Jordan are still suffering from a shortage in work forces which is around 73.3\% employment capacity. Whereas Magableh (2000) stated that the reasons behind the little involvement of women in tourism services in Jordan are due to culture and traditions which prevents women from working long hours beside working at night in the hotel where alcoholic drinks are served which is against Islamic principles and norms, in addition, the women's role as household and their lack of experience in hotel services. The social and cultural factors affecting on students the choice to enroll hospitality studies (Alananzeh, 2014). Magableh (2005) shed lights on the positive advantages of working in the tourism industry as perceived by Jordanian women, they study showed that women truly realize that there are some positive advantages like meeting new people, knowing other cultures, self-fulfillment, and the ease and enjoyment of tourism jobs.

\subsection{The Barriers and Obstacles}

Hotel education for women helps them to increase their participation in the labor markets (Hotel) and increase their family income, which benefits the whole community and releases the stress on employment demand. Thus, working in hotel sector has a positive income on per capita income and since the woman is part of this community, working in hotels will grantee her and her family a better life. Magableh (2000) stated that traditions and cultures are preventing women from working for long hours. In additions, community abhorrences women from working in places where the alcoholic is served which violate Islamic teachings and principles. He also postulated that women's lack of practical experiences and scientific qualifications is the most important barrier that hinders women from working in the hospitality sector. Women as well feel that they do not have a clear job description or adequate promotion opportunities. Whereas, (Alananzeh, 2017; Al-saman (2002) claimed that 
tourism is affected by the surrounding political events and that may cause hospitality properties to face hard times and which may lead to the lack of employments or late payment of salaries. Meanwhile, Al-Zou'by and Alkharouf (2015) mentioned some more obstacles that prevent women from joining hospitality jobs; these are the community conservation regarding women's travel for the purpose of work; the tradition and cultures refuses the woman to stay late in her job or office; some jobs in tourism as opposed to the religious beliefs; the difficulty of reconciling between home duties and job duties; the possibility of being exposed to sexual harassment in her work places, and finally women believe that those who are working in hospitality sector may not get an opportunity for marriage or get it late because of the community attitude towards such women.

\section{Research Methodology}

This section provides the methodology applied in the current study. It consists of the research operational definitions of the study's variables, besides data collection tool and research population and sample.

\subsection{Research Operational Definitions}

The current research considers four barriers prevent female students from studying hotel management as a major in the faculties of tourism and hospitality. These factors include the financial aspects, cultural and social standpoints, religious perspective, and geographical reason; which were measured in the research questionnaire through five, nine, five, and five items respectively.

\subsection{Population and Sampling}

The targeted population is defined as all individuals or items that are suffering from the same problem of the study or is related to it (Al-Zou'by and Alkharouf, 2015). Thus, the population of this study is the girl students / Aqaba branch of the University of Jordan in five colleges; College of Business Administration, Faculty of Languages, Faculty of Tourism and Hotel Management, Faculty of Information Technology as these disciplines commensurate with the work in the tourism sector. According to the registration department database for the academic year 2015/2016, the University of Jordan- Aqaba branch, the number of girl students in these five colleges consisted of 530 and distribution of the number of the girls according to each college was almost closed, and according to Morgan Table data, 214 respondents should be reached as the size of statistical sample of this research (Sekaran and Bougie, 2013). However, 209 survey questionnaires were returned from respondents and considered 200 after eliminating the incomplete ones. The primary data was collected through a drop-and-collect survey technique. The surveys were distributed to the students in their classes and collected after each class ended. The questionnaire consisted of two sections; the first section in questionnaire presents general personal information about a respondent, the University Stage, College, Major, Household Income, academic level for your father, academic level for your Mother and Original Place of Residence. The second section includes a descriptive Analysis of questions to measure the variables based on their operational definitions. 


\section{Data Analysis and Results}

In order to explore the degree to which female students face barriers that put off them from studying hotel management as a major in tourism and hospitality sectors at the University of Jordan / Aqaba branch, in which the items for these barriers have been measured using 5 -points Likert scale that varies between strongly disagree $=1$, and strongly agree $=5$; reliability and validity analyses were conducted, descriptive analysis was used to describe the characteristic of sample and the respondents to the items of the questionnaire.

\subsection{Validity and Reliability}

Validity and reliability are two important measures to determine the quality and usefulness of the primary data. Validity is about accuracy and whether the instrument measures what it is intended to measure while reliability is about precision; it is used to check the consistency and stability of the questionnaire. Indeed, the researchers depended on scales and items that were previously developed and used by other researchers with similar interest. Also, a draft of the questionnaire was formulated, and then it was reviewed by four academic lecturers -who have a sufficient knowledge and experience in this scope- to ensure that each item is measuring what is intended to be measured and to avoid the ambiguity and complexity in the phrasing of questions. The reliability of the instrument was measured by the Cronbach's alpha coefficient. Further, some scholars (e.g. Bagozzi and Yi, 1988; Creswell, 2009) suggested that the values of all indicators or dimensional scales should be above the recommended value of 0.60. Table (1) represents the results of Cranach's alpha for the study barriers. Cronbach's alpha coefficients of all the tested variables are above 0.60 which suggesting the composite measure is reliable.

Table 1. The Cronbach's alpha coefficients of study variables/ barriers

\begin{tabular}{|l|l|l|}
\hline Variables/ Barriers & Number of items & $\begin{array}{l}\text { Cronbach } \\
\text { alpha }\end{array}$ \\
\hline Financial Barriers & 5 & 0.762 \\
\hline Cultural and Social Barriers & 9 & 0.827 \\
\hline Religious Barriers & 5 & 0.744 \\
\hline Geographical Barriers & 5 & 0.734 \\
\hline
\end{tabular}

\subsection{Respondents Demographic Profile}

As indicated in Table (2), the demographic profile of the respondents for this study showed that they originally from Aqaba; most of them in their fourth year study; the majorities from the college of Management and Finance, and Tourism and Hospitality respectively; and most of their household income more than 1000 \$ a month. 
Table 2. Description of the respondents' demographic profiles

\begin{tabular}{|c|c|c|c|}
\hline Category & Category & Frequency & Percentage \% \\
\hline \multirow[t]{5}{*}{ University stage } & First Year & 43 & 21.5 \\
\hline & Second Year & 39 & 19.5 \\
\hline & Third Year & 54 & 27.0 \\
\hline & Fourth Year & 64 & 32.0 \\
\hline & Total & 200 & 100 \\
\hline \multirow[t]{5}{*}{ College } & Management and Finance & 81 & 40.5 \\
\hline & Information Technology & 16 & 8.0 \\
\hline & Tourism and Hospitality & 64 & 32.0 \\
\hline & Languages & 39 & 19.5 \\
\hline & Total & 200 & 100 \\
\hline \multirow[t]{12}{*}{ Major } & English Language & 21 & 10.5 \\
\hline & French Language & 15 & 7.5 \\
\hline & Arabic Language & 3 & 1.5 \\
\hline & $\begin{array}{l}\text { Tourism \& } \begin{array}{l}\text { Travel } \\
\text { Management }\end{array} \\
\end{array}$ & 33 & 16.5 \\
\hline & Hotel Management & 12 & 6.0 \\
\hline & $\begin{array}{lrl}\text { Food \& } \quad \text { Beverage } \\
\text { Management }\end{array}$ & 19 & 9.5 \\
\hline & $\begin{array}{ll}\text { Computer } & \text { Information } \\
\text { Systems } & \end{array}$ & 3 & 1.5 \\
\hline & $\begin{array}{ll}\text { Business } & \text { Information } \\
\text { Technology } & \\
\end{array}$ & 13 & 6.5 \\
\hline & Accounting & 32 & 16 \\
\hline & Business Administration & 26 & 13 \\
\hline & $\begin{array}{l}\text { Rist Management \& } \\
\text { Insurance }\end{array}$ & 23 & 11.5 \\
\hline & Total & 200 & 100 \\
\hline \multirow{5}{*}{$\begin{array}{l}\text { Household } \\
\text { income (\$ per } \\
\text { month) }\end{array}$} & Less than $450 \$$ & 18 & 9.0 \\
\hline & $450-$ less than $700 \$$ & 41 & 20.5 \\
\hline & $700-$ less than $1000 \$$ & 39 & 19.5 \\
\hline & More than $1000 \$$ & 102 & 51.0 \\
\hline & Total & 200 & 100 \\
\hline \multirow{6}{*}{$\begin{array}{l}\text { The academic } \\
\text { level for the } \\
\text { student's father }\end{array}$} & High School Level or Less & 89 & 44.5 \\
\hline & Diploma & 54 & 27.0 \\
\hline & Bachelor & 50 & 25.0 \\
\hline & Master & 5 & 2.5 \\
\hline & Doctorate & 2 & 1.0 \\
\hline & Total & 200 & 100 \\
\hline \multirow{2}{*}{\begin{tabular}{ll} 
The & \multicolumn{2}{c|}{ academic } \\
level for the
\end{tabular}} & High School Level or Less & 65 & 32.5 \\
\hline & Diploma & 49 & 24.5 \\
\hline
\end{tabular}




\begin{tabular}{|l|l|l|l|}
\hline student's mother & Bachelor & 74 & 37.0 \\
\cline { 2 - 4 } & Master & 10 & 5.0 \\
\cline { 2 - 4 } of residency & Doctorate & 2 & 1.0 \\
\cline { 2 - 4 } & Total & 200 & 100 \\
\hline \multirow{5}{*}{$\begin{array}{l}\text { Original place } \\
\text { Irbid }\end{array}$} & 10 & 5.0 \\
\cline { 2 - 4 } & Amman & 31 & 15.5 \\
\cline { 2 - 4 } & Aqaba & 121 & 60.5 \\
\cline { 2 - 4 } & Ajlun & 7 & 3.5 \\
\cline { 2 - 4 } & Al-Karak & 15 & 7.5 \\
\cline { 2 - 4 } & Tafiela & 9 & 4.5 \\
\cline { 2 - 4 } & Jarash & 0 & 0 \\
\cline { 2 - 4 } & Ma'an & 4 & 2.0 \\
\cline { 2 - 4 } & Al-Balqa & 1 & 0.5 \\
\cline { 2 - 4 } & Al-Zarqa & 1 & 0.5 \\
\cline { 2 - 4 } & Madaba & 1 & 0.5 \\
\cline { 2 - 4 } & Al-Mafraq & 200 & 100 \\
\cline { 2 - 4 } & Total & & 0 \\
\hline
\end{tabular}

\subsection{Descriptive Analysis}

In order to describe the responses and thus the attitude of the respondents toward each question, they were asked in the survey, the mean and the standard deviation were estimated. While the mean shows the central tendency of the data, the standard deviation measures the dispersion which offers an index of the spread or variability in the data (Pallant, 2005; Sekaran and Bougie, 2013). In other words, a small standard deviation for a set of values reveals that these values are clustered closely about the mean or located close to it; a large standard deviation indicates the opposite. The level of each item was determined by the following formula: (highest point in Likert scale - lowest point in Likert scale) / the number of the levels used $=(5-1) / 5=0.80$, where 1-1.80 reflected by "very low", 1.81-2.60 reflected by "low", 2.61-3.40 reflected by "moderate", 3.41-4.20 reflected by "high", and 4.21-5 reflected by "very high". Then the items were being ordered based on their means. Tables (3) and (4) show the results.

Table 3. Overall mean and standard deviation of the study's variables

\begin{tabular}{|l|l|l|l|l|}
\hline Type of Variable/ Barrier & Mean & Standard Deviation & Level & Order \\
\hline Financial Barriers & 3.4950 & 0.88968 & High & 4 \\
\hline Cultural and Social Barriers & 3.7344 & 0.69632 & High & 3 \\
\hline Religious Barriers & 3.8200 & 0.84259 & High & 1 \\
\hline Geographical Barriers & 3.7600 & 0.76006 & High & 2 \\
\hline
\end{tabular}

As presented in Table (3), data analysis results have shown that barriers face female students from studying hotel management as a major in the faculties of tourism and hospitality are applied to high levels in which the range of the mean score are 3.4950-3.8200. Table (4) 


\section{Ml Macrothink}

demonstrates the mean, standard deviation, level, and order scores for items for each variable/barrier.

Table 4. Mean and standard deviation of the study's variables

\begin{tabular}{|c|c|c|c|c|}
\hline Financial Barriers & Mean & SD & Level & $\begin{array}{l}\text { Or } \\
\text { der }\end{array}$ \\
\hline $\begin{array}{l}\text { The family's low standard of living to study Hotel } \\
\text { Management as a major }\end{array}$ & 3.42 & 1.339 & High & 3 \\
\hline $\begin{array}{l}\text { The difficulty of finding a job after graduation from the } \\
\text { university majoring in Hotel Management }\end{array}$ & 3.52 & 1.232 & High & 2 \\
\hline $\begin{array}{l}\text { Few programs that highlight the importance of women's } \\
\text { work in the tourism sector }\end{array}$ & 3.89 & 1.021 & High & 1 \\
\hline $\begin{array}{l}\text { High standard of living in Aqaba prevents me from } \\
\text { coming to study Hotel Management }\end{array}$ & 3.25 & 1.329 & $\begin{array}{l}\text { Moder } \\
\text { ate }\end{array}$ & 5 \\
\hline $\begin{array}{l}\text { The low salary that a girl could achieve in tourism sector } \\
\text { comparing to other companies and institutions }\end{array}$ & 3.41 & 1.268 & High & 4 \\
\hline Cultural and Social Barriers & Mean & SD & Level & $\begin{array}{l}\text { Or } \\
\text { der }\end{array}$ \\
\hline $\begin{array}{l}\text { The community is conservative regarding women's } \\
\text { travel for the purposes of hotel working }\end{array}$ & 4.09 & 0.976 & High & 1 \\
\hline $\begin{array}{l}\text { The spread of the culture of shame in the community } \\
\text { regarding women's work in tourism and hotel sector }\end{array}$ & 3.90 & 1.039 & High & 3 \\
\hline $\begin{array}{l}\text { The community is conservative regarding women's } \\
\text { going out late for the purposes of hotel work }\end{array}$ & 4.01 & 1.049 & High & 2 \\
\hline $\begin{array}{l}\text { The difficulty of performing social duties for women } \\
\text { working in the hotel sector }\end{array}$ & 3.56 & 1.031 & High & 8 \\
\hline $\begin{array}{l}\text { The difficulty of securing children for women working in } \\
\text { hotel sector }\end{array}$ & 3.57 & 1.123 & High & 7 \\
\hline $\begin{array}{l}\text { The limited of tourism professions that the society allows } \\
\text { women to work in }\end{array}$ & 3.65 & 1.012 & High & 5 \\
\hline $\begin{array}{l}\text { The difficulty of performing home duties for women } \\
\text { working in hotel sector }\end{array}$ & 3.46 & 1.198 & High & 9 \\
\hline $\begin{array}{l}\text { The society imposes limited field in hotel sector for the } \\
\text { women in }\end{array}$ & 3.60 & 1.075 & High & 6 \\
\hline $\begin{array}{l}\text { The community is conservative regarding women's } \\
\text { work in mixed places such as hotels }\end{array}$ & 3.80 & 1.157 & High & 4 \\
\hline Religious Barriers & Mean & SD & Level & $\begin{array}{l}\text { Or } \\
\text { der }\end{array}$ \\
\hline $\begin{array}{l}\text { The rejection of Islam regarding girl's mixing with males } \\
\text { from different nationalities }\end{array}$ & 3.75 & 1.276 & High & 4 \\
\hline $\begin{array}{l}\text { Religious teachings reject the work of girls in a hotel that } \\
\text { offers alcoholic beverages }\end{array}$ & 3.99 & 1.136 & High & 1 \\
\hline Religion does not allow girls to be in the places of their & 3.97 & 1.120 & High & 2 \\
\hline
\end{tabular}




\begin{tabular}{|l|l|l|l|l|}
\hline work for hours late at night & & & & \\
\hline $\begin{array}{l}\text { Religion stands negatively against women working in the } \\
\text { tourism and hospitality sector }\end{array}$ & 3.58 & 1.233 & High & 5 \\
\hline $\begin{array}{l}\text { Most businesses prefer men rather than women for } \\
\text { religious reasons }\end{array}$ & 3.82 & 1.223 & High & 3 \\
\hline Geographical Barriers & Mean & SD & Level & $\begin{array}{l}\text { Or } \\
\text { der }\end{array}$ \\
\hline $\begin{array}{l}\text { The availability of Hotel Management Programs } \\
\text { (Bachelor's) in a limited Jordanian universities in some } \\
\text { provinces }\end{array}$ & 3.87 & 1.118 & High & 1 \\
\hline $\begin{array}{l}\text { The lack of postgrduate programs in Hotel Management } \\
\text { in the Jordanian universities }\end{array}$ & 3.75 & 1.079 & High & 4 \\
\hline $\begin{array}{l}\text { Girl students hate and refuse to stay away from their } \\
\text { families to study Hotel Management specialization }\end{array}$ & 3.66 & 1.115 & High & 5 \\
\hline $\begin{array}{l}\text { Hotel facilities are concentrated in a specific geographic } \\
\text { area (Amman, Aqaba, Wadi Musa, the Dead Sea) }\end{array}$ & 3.77 & 1.066 & High & 2 \\
\hline $\begin{array}{l}\text { There is a large number of hotel facilities located in } \\
\text { isolated geographic areas like (Aqaba, Wadi Musa, the } \\
\text { Dead Sea) }\end{array}$ & 3.76 & 1.081 & High & 3 \\
\hline
\end{tabular}

\section{Conclusions}

Since the hotel management major was officially launched in the University of JordanAqaba branch in 2009, but up to this year, 2016, only six female students have joined this bachelor program. Therefore, this study was conducted to explore the factors or barriers that prevent female students from studying hotel management as a major at the faculty of tourism and hospitality. Several factors were suggested in the Jordanian community context. These factors include the financial aspects, cultural and social standpoints, religious perspective, and geographical reason. Elder women are blocked from the promotion in their career development in the hotel industry,( Yun Yang,2011). Women employees have to face "Gender Segregation" in their career development, which is described as a "glass ceiling" vividly or "horizontal sex segregation" (Anker, 2004). Low-level education is often considered as one of the main obstacles for the promotion of women (Bullard, Wright's, 1993; Schruijer, 2006).

Results revealed that the religious barrier was ranked as the first barrier that hinders female students from joining hotel management program. Women still believe that Religious teachings reject the work of girls in a hotel that offers alcoholic beverages. The community still refuses women to stay late at night in their work. Also, people still believe Islam rejects the girl's mixing with others especially males from different nationalities, but they have to understand that Islam has clear fair principles and regulations regarding females dealing with others in presenting services and doing jobs. Therefore, business prefers men over women in order to avoid the shortage in the workforce at their hotel. It is the duty of the public and private sector, the Ministry of Education and other social societies to clarify the Islamic attitude towards women's employment in public jobs. 
The findings of the study showed that the geographic factor has shown the second as the most important factor which affects on girls in enrolling Hotel Management Department at the University of Jordan / Aqaba Branch. Female students referred this to the shortage of this major to some provinces in Jordan. Then the other obstacle is that hotel facility are concentrated in a specific geographic area (Amman, Aqaba, Wadi Musa, the Dead Sea) where the population density is very low except for Amman where there is no such major. Whereas, Aqaba, Wadi Rum, and the Dead Sea are considered isolated areas. The lack of a postgraduate program for Hotel management in Jordan also hindered female students from joining bachelor program, in addition, girl students hate and refuse to stay away from their families to study hotel management specialization. We recommend that the government and the university should provide facilities devoted for girl students to overcome the difficulties and change their attitudes towards joining such major in the isolated provinces such as Aqaba. In addition, we recommend the University of Jordan in Amman to start a postgraduate program in hotel management as soon as possible.

The cultural and social factor is the third factor that affects the lack of girls to joining hotel management at the University of Jordan/Aqaba Branch. The results showed that the community is conservative regarding women's travel for the purposes of hotel working and going out late for the purposes of hotel work. Most parts of the community still have the notion of shame regarding women's work in tourism and hotel sector or mixing with strange people. Indeed, several researchers consider the information systems and in particular the Information Technology (IT) and Knowledge Management (KM) systems as an enabler to achieve the desired competitive advantages, and as a crucial support to operational and strategic business decisions (Alshurideh and Alkurdi, 2012; Hajir et al., 2015; Masa'deh et al., 2012-2017); consequently, further research is required to examine the presence of special awareness programs regarding such cultural obstacles. In addition to the limited profession offered for women in hotels or the difficulties the married women working in hotels to secure their kids during hours-work or the difficulty of performing social duties for women working in the hotel sector.

The financial barrier was shown to be forth barrier from the point of view of the university' girl students. They claimed that few programs that highlight the importance of women's work in the tourism sector. There are reports that the sector has a particularly poor image in the eyes of hospitality students, which suggests that the industry may have greater difficulty attracting, recruiting and retaining quality staff (Jenkins, 2001). Other maintained that there is the difficulty of finding a job after graduation from the university majoring in hotel management or they will get a low salary in hotels. Whereas, other students stated that high standard of living in Aqaba prevents them from coming to study hotel management.

This study shall provide important feedback to decision-makers to encourage the female students further in studying hotel management degree specifically in Aqaba city. They should work on empowering women to hold senior leadership positions in tourism and Hotel industry. They should raise the awareness regarding our customs, traditions, cultures and social practices that devoted stereotype towards women work in hotels and educating women about their rights. Create advanced training centers specialized in tourism professions to 
qualify women to enter the tourism labor market. We also recommend that educational institution should launch awareness campaigns to shed light on the importance of tourism industry and the role of women in this sector. The university of Jordan should adopt policies and strategies to attract girl students to study hotel management and to be a pioneer in such major.

Studying and working in hospitality is restricted by the Islamic values. The Islamic Personal Law affects women's participation in working forces in the Arabian societies (karnen, 1996; kazimi,2000).

In the Middle East, some studies indicated that most countries one ruled diversely by the Islamic law, some writers pointed out that these rules especially inheritance, children custody rights and divorce distinguish between the two genders.

Kazimi mentioned that some religious rules are immutable to be changed to equalize both male and female in some laws (Kazimi, 2000).

The attitude toward women's study and work) mainly and diversely depends on religion and tribal traditions which have a notable effect on types of jobs women have in different economic fields. For example, the parental authority i.e, the father's dominating role, is a key aspect in the Middle East societies, moreover, this attitude changes quietly into the equality between genders regarding studying and working in hospitality.

Consequently, women may face many religious, cultural, and social restrictions in studying and working in hospitality fields. Experimental studies, therefore, should highlight these restrictions mainly when the Arabian women, such as Saudi women after the vision of K.S.A in 2030 , enter the hospitality business.

The researcher believes that the increasing number of educated and employed women may derestrict the religious, cultural, and social limits. It's worth to mention that these issues need to be studied particularly in both conservative and open societies.

\section{References}

Alananzeh, O. A. (2017). Impact of Safety Issues and Hygiene Perceptions on Customer Satisfaction: A Case Study of Four and Five Star Hotels in Aqaba, Jordan. Journal of Tourism Research \& Hospitality, 6(1). https://doi.org/10.4172/2324-8807.1000161

Alananzeh, O. A. (2015). Exploring the Factors Influencing Students in Enrolling Tourism and Hospitality Management Colleges in Jordan: A Case Study in Aqaba Economic Zone. Journal of Management Research, 6(2), 61-73. https://doi.org/10.5296/jmr.v6i2.5257

Alananzeh, O. A., Mahmoud, R.M., \& Ahmed, M.N.J. (2015). Examing the Effect of High Seasonality on Fronline Employees: A Case Study of Five Star Hotel in Aqaba. European Scientific Journal, 11(32), 330-341.

Anker, R. (2004). Gender and Jobs: Sex Segregation of Occupations in the World, International Labor Office, Geneva. 
Al-Hussein, M.A., Jawabreh, O.A., Alananzeh, O.A., \& Ali, M.M. ( 2015). The Impact of Understanding the Behavior of Workers on the Success of Management (A Case Study of Five Star Hotels in Aqaba). Journal of Management Research, 7(3), 51-70. https://doi.org/10.5430/ijba.v8n4p49

Al-saman, R, F, J. (2002). The Difficulties that Face Female Workers in Tourism Sector. Unpublished Master Thesis, the University of Jorda, Amman.

Alsarayreh, M., Abed Alqader, S., \& Jawabreh, O. (2010). The Effect of Training Courses for Students in Tourism and Hotel Management of Students Social Skills. Journal of West Asian Studies, 24(1).

Alshawagfih, K.F., Alananzeh, O.A., \& Jawabreh, O.A. (2015). The Foundations of Selecting Cultural Tourism Product in Jordan. European Scientific Journal, 11(29), 198-217.

Alshurideh, M., \& Alkurdi, B. (2012). The Effect of Customer Satisfaction on Customer Retention in the Jordanian Mobile Market: An Empirical Investigation. European Journal of Economics, Finance and Administrative Sciences, 47, 69-78.

Al-Zou'by, R, F., \& Alkharouf, A, M. (2015). The Attitude of Young Men from Women Work in Tourism Industry: A Case Study of the Students in the University of Jordan. Jordanian Journal for Social Sciences, 8(1), 67-107.

Bagozzi, R., \& Yi, Y. (1988). On the Evaluation of Structural Evaluation Models. Journal of the Academy of Marketing Science, 16(1), 74-94. https://doi.org/10.1007/BF02723327

Bazazo, I.K., \& Alananzeh, O.A. (2016). The Effect of Electronic Tourism in Enabling the Disabled Tourists to Communicate with the Touristic and Archaeological Sites Case Study-Jordan. European Scientific Journal, 12(5), 111-128.

Bazazo, I.K., Alananzeh, O.A., \& Taani, A.A. (2016). Marketing the Therapeutic Tourist Sites in Jordan Using Geographic Information System. European Journal of Business and Management, 8(30), 29-39.

Bazazo, I.K., Alananzeh, O.A., Adas, K., \& Alshawagfih, K.F. (2016). The Role of the Transformational Leadership in Enhancing the Social Responsibility at the Five Stars Hotels in the Hashemite Kingdom of Jordan. European Journal of Business and Management, 8(23), 67-74.

Bullard, A.M. and Wright, D.S. (1993). Circumventing the glass ceiling: women executives in American state governments. Public Administration Review, 3, 189-202. https://doi.org/10.2307/3110123

Burke, R. J., Koyuncu, M., \& Fiksenbaum, L. (2008). Work Experiences, Satisfactions and Psychological Well-being of Female and Male Managers in the Hospitality Sector in Turkey. Equal Opportunities International, 27(6), 505-518. https://doi.org/10.1108/02610150810897273

Chiu, L. K., \& Ananzeh, O. A. (2012a). Evaluating the Relationship between the Role of 
Promotional Tools in MICE Tourism and the Formation of the Touristic Image of Jordan. Tourism and Innovation Journal, 5(1), 59-73.

Chiu, L. K., \& Ananzeh, O. A. (2012b). The role of MICE Destination Attributes on Forming Jordan Touristic Image. Academic Research International, 3(1), 267-277.

Creswell, J. (2009). Research Design: Qualitative, Quantitative, and Mixed Methods Approaches. (3rd edition), Thousand Oaks: Sage Publications.

Doherty, L. (2004). Work-life Balance Initiatives: Implications for Women. Employee Relations, 26(4), 433-452. https://doi.org/10.1108/01425450410544524

Fall, L. T. (2002). Examining the Economic Value of Publicity and Promotional Activities among State Tourism Communication Programs. Journal of Promotion Management, 8(2), 35-46. https://doi.org/10.1300/J057v08n02_04

Hackett, C. (1981). The Woman Food and Beverage Manager. The Cornell Hotel and $\begin{array}{llll}\text { Restaurant Administration } \quad \text { Quarterly, } & \text { 22(3), }\end{array}$ https://doi.org/10.1177/001088048102200321

Hajir, J., Obeidat, B., \& Al-dalahmeh, M. (2015). The Role of Knowledge Management Infrastructure in Enhancing Innovation at Mobile Telecommunication Companies in Jordan. European Journal of Social Sciences, 50(3), 313-330.

Hodur, N.M., \& Leistritz, F.L. (2006). Estimating the Economic Impact of Event Tourism: A Review of Issues and Methods. Journal of Convention \& Event Tourism, 8(4), 63-79. https://doi.org/10.1300/J452v08n04_05

Jawabreh, O.A., Alananzeh, O.A., \& Shatnawi, H.S. (2015). Managing Tourism Effects for Attitudes of Jordanians Towards Tourism: The Case of Petra. European Journal of Social Sciences, 48(1), 73-84.

Jenkins, A.K. (2001). Making a Career of it? Hospitality Students' Future Perspectives: An Anglo-Dutch Study. International Journal of Contemporary Hospitality Management, 13(1), 13-20. https://doi.org/10.1108/09596110110365599

Karmi, G. (1996). Women, Islam and patriarchalism. in Yamani, M. (Ed.), Feminism \& Islam, New York University Press, New York, NY, pp. 69-85.

Kazemi, F. (2000). Gender, Islam and politics. Social Research, 67(2), 22-34.

Kim, S.S., Lee, M.J., \& Chon, K. (2008). Study Motivations and Study Preferences in the Korean Hospitality and Tourism Field. Journal of Marketing for Higher Eduealion, 18(2), 216-239. https://doi.org/10.1080/08841240802487395

Lashley, C. (1999). On Making Silk Purses: Developing Reflective Practitioners in Hospitality Management Education. International Journal of Contemporary Hospitality Management, 11(4), 180-185. https://doi.org/10.1108/09596119910263586

Magableh, K, M. (2000). The Reality of Women Participation in Work Force in Hospitality 
Sector in Jordan. Aledari Journal, 83, 183-209.

Magableh, K, M. (2005). The Dimension of Women Participation Working in Tourism Sector. Alyarmouk Journal, 95-122.

Masa'deh, R. (2012). The Impact of Management Information Systems (MIS) on Quality Assurance (QA): A Case Study in Jordan. International Journal of Information, Business, and Management, 93-110.

Masa'deh, R., Gharaibeh, A., Maqableh, M., \& Karajeh, H. (2013). An Empirical Study of Antecedents and Outcomes of Knowledge Sharing Capability in Jordanian Telecommunication Firms: A Structural Equation Modeling Approach. Life Science Journal, 10(4), 2284-2296.

Masa'deh, R., Gharaibeh, A., Tarhini, A., \& Obeidat, O. (2015). Knowledge Sharing Capability: A Literature Review. In Fourth Scientific \& Research Conference on New Trends in Business, Management and Social Sciences, Istanbul, Turkey, 19-20 September 2015, 1-16. https://doi.org/10.2139/ssrn.2696924

Masa'deh, R., Maqableh, M., \& Karajeh, H. (2014). A Theoretical Perspective on the Relationship between Leadership Development, Knowledge Management Capability, and Firm Performance. Asian Social Science, 10(6), 128. https://doi.org/10.5539/ass.v10n6p128

Masa'deh, R., Shannak, R., Maqableh, M., \& Tarhini, A. (2017). The Impact of Knowledge Management on Job Performance in Higher Education: The Case of the University of Jordan. Journal of Enterprise Information Management, 30(2), 244-262. https://doi.org/10.1108/JEIM-09-2015-0087

Maxwell, G., McDougall, M., \& Blair, S. (2000). Managing Diversity in the Hotel Sector: The Emergence of a Service Quality Opportunity. Managing Service Quality: An International Journal, 10(6), 367-373. https://doi.org/10.1108/09604520010351176

Meehan, E. R. (2008). Tourism, Development, and Media. Society, 45(4), 338-341. https://doi.org/10.1007/s12115-008-9111-7

Moghadam, V. (1992). Women, employment and social change in the Middle East and North Africa. in Kahne, H. and Giele, J. (Eds), Women's Work and Women's Lives: The Continuing Struggle Worldwide, Westview Press, Boulder, pp. 87-116

Mooney, S., \& Ryan, I. (2009). A Woman's Place in Hotel Management: Upstairs or Downstairs?. Gender in Management: An International Journal, 24(3), 195-210. https://doi.org/10.1108/17542410910950877

Pallant, J. (2005). SPSS Survival Manual: A Step Guide to Data Analysis Using SPSS for Windows Version 12. Chicago, Illinois: Open University Press.

Riley, M., Ladkin, A., and Szivas, E. (2002). Tourism Employment: Analysis and Planning. Channel View Publications, Sydney.

Schruijer,S.G. (2006). Do Women Want to Break the Glass Ceiling? A Study of their Career 


\section{Macrothink}

Journal of Management Research

ISSN 1941-899X 2017, Vol. 9, No. 4

Orientations and Gender Identity in The Netherlands. Management Revue, 2, 143-154, http://hdl.handle.net/10419/78890

Sekaran, U., \& Bougie, R. (2013). Research Methods for Business: A Skill-Building Approach, (6th edition), New York :Wiley.

Sharpley, R. (2002). The Challenges of Economic Diversification through Tourism: The Case of Abu Dhabi. International Journal of Tourism Research, 4(3), 221-235. https://doi.org/10.1002/jtr.378

Taraki, L. (1995). Islam is the solution: Jordanian Islamists and the dilemma of the modern woman. The British Journal of Sociology, 46(4), 643-61. https://doi.org/10.2307/591576

Yun Yang (2011).Gender and Engineering Career Development of Hotel's Employees in China, International Conference on Risk and Engineering Management. Systems Engineering Procedia, 1, 365-371. https://doi.org/10.1016/j.sepro.2011.08.055 